\title{
Phycoremediation of wastewaters: a synergistic approach using microalgae for bioremediation and biomass generation
}

\author{
N. Renuka $\cdot$ A. Sood $\cdot$ R. Prasanna $\cdot$ \\ A. S. Ahluwalia
}

Received: 17 April 2014/Revised: 18 September 2014/Accepted: 22 October 2014/Published online: 18 November 2014

(C) Islamic Azad University (IAU) 2014

\begin{abstract}
Discharge of untreated domestic and industrial wastewater into aquatic bodies is posing a serious eutrophication threat, leading to a slow degradation of the water resources. A number of physical, chemical and biological methods have been developed for the treatment of wastewaters; among these, the use of microalgae is considered as a more eco-friendly and economical approaches. Microalgae are versatile organisms which perform multiple roles in the environment-bioremediation of wastewater, gleaning of excess nutrients and in turn, generate valuable biomass which finds applications in the food, biofuel and pharmaceutical industries. They are currently being utilized to reduce the high nutrient load (especially $\mathrm{N}$ and $\mathrm{P}$ ) from wastewaters, which fulfill the growth requirements of microalgae, making it a suitable cultivation medium for biomass production. The present review represents a comprehensive compilation of reports on microalgal diversity of wastewaters, followed by a critical overview of their utilization, suitability and potential in bioremediation vis-a-vis biomass production. This review also emphasizes the superiority of polyalgal and consortial approaches in wastewater treatment, as compared to the use of unialgal inocula, besides providing useful pointers for future research needs in this area.
\end{abstract}

Keywords Wastewater - Eutrophication - Microalgal diversity $\cdot$ Consortia $\cdot$ Nutrient removal $\cdot$ Biomass production

N. Renuka · A. S. Ahluwalia ( $₫)$

Department of Botany, Panjab University,

Chandigarh 160014, India

e-mail: aas.aca2012@gmail.com

A. Sood $\cdot$ R. Prasanna

Division of Microbiology, Indian Agricultural Research

Institute, New Delhi 110012, India

\section{Introduction}

Issues related to environmental pollution are becoming more serious with the increasing population, urbanization, industrialization and their indirect effects on ecosystem services (Rawat et al. 2011; Sood et al. 2012). The consequences include excessive generation of wastes/wastewater, release of untreated water into the freshwater resources and global warming, which are posing serious challenges for the scientific community, in terms of sustainability of our planet for the present as well as future generations. Each facet of environment pollution has its own list of problems which require specified know-how and technologies to meet and overcome the challenge. In this context, mixing of untreated wastewater in aquatic bodies is emerging up as one of the major issues that is challenging the stability of nations (Renuka et al. 2014; Yang et al. 2008). This is mainly due to the reason that the majority of populations in developing countries are directly or indirectly dependent on the freshwater resources for their day-to-day activities.

In developing countries like India, water scarcity is presenting serious issues, because of population explosion resulting in large quantities of sewage wastewater. Coupled with this, increasing industrialization, indiscriminate and excessive usage of fertilizers and pesticides is resulting in contamination/mixing of untreated wastewater with the available water resources (El-sheekh et al. 2000; Ghosh et al. 2012). The report of World Health Organization (WHO 2000) and a survey of Central Pollution Control Board, India (CPCB 2009) stated that only 31 and $35 \%$ of the total sewage wastewater is treated up to secondary level in Asia and urban cities of India, respectively, with a capacity gap of 65-69\%. Further, the presence of excess nutrients $(\mathrm{N}$ and $\mathrm{P})$ in untreated wastewater is resulting in 
eutrophication, algal blooms, uncontrolled spread of certain aquatic macrophytes, oxygen depletion and loss of key floral and faunal species, leading to the total degradation of water bodies (Khan and Ansari 2005). Therefore, there is a need to identify cost-effective, eco-friendly technologies that require minimal infrastructure, inputs and simple know-how, which can be utilized by the common man or less literate population. These technologies should also be applicable at the small-scale level with potential of acceptance at commercial level in the future.

The methods applied in the treatment of effluents or contaminated water are broadly classified into three types-physical, chemical and biological (Fig. 1). These can be employed individually or in combination, depending upon the extent and type of pollution. In order to achieve the desired levels of contaminant removal, individual wastewater treatment procedures are grouped into a variety of systems, classified as primary, secondary and tertiary wastewater treatments. In general, both physical and chemical methods are costly. Also, most chemical methods increase the $\mathrm{pH}$, conductivity and overall load of dissolved matter in the wastewater. In this respect, biological or biotreatment of wastewater is a better option. The most common biological wastewater treatment applied in the treatment of municipal and industrial wastewaters is the use of activated sludge alone (Nyholm et al. 1996; Radjenovic et al. 2009) or in combination with algae (Gonzalez et al. 2008; Su et al. 2012a). However, problems related to dewatering and disposal of sludge have made researchers look for other alternatives.

Phytoremediation, the use of plants (including algae or lower plants) and associated microflora for the removal or biotransformation of pollutants including nutrients, heavy metals etc. from wastewater seems to be a promising option (Ali et al. 2013; Franchino et al. 2013; Richards and Mullins 2013; Sood et al. 2012). Oswald and Gotaas (1955) are the pioneers in this area, especially in terms of illustrating the potential of algae in the wastewater treatment. Oswald et al. (1957) reported designs of natural treatment systems empowered primarily by solar energy, making wastewater treatment more affordable and sustainable. Wastewater treatment with microalgae, also referred to as Phycoremediation, is a term coined recently by John (2000), as given by Souza et al. (2012). Phycoremediation is particularly attractive because it has the ability to deal with more than one problem on-site. The promising attributes of microalgae, such as (1) higher photosynthetic capabilities as compared to higher plants (Bhatnagar et al. 2011), (2) ability to convert solar energy and $\mathrm{CO}_{2}$ emissions from power plants, hence, lower energy requirements (Razzak et al. 2013), (3) capacity to incorporate excess nutrients such as nitrogen and phosphorus from sewage water for their growth, making disposal easy (Bhatnagar et al. 2011; Mata et al. 2012),
(4) tolerance to extreme conditions (Makandar and Bhatnagar 2010), (5) ability to reduce greenhouse gas emissions (Bhola et al. 2014; Singh and Ahluwalia 2013), (6) wide applications of harvested biomass (Gupta et al. 2013). These useful features of microalgae have further strengthened their exploitation in wastewater treatment, as compared to the use of higher aquatic macrophytes (Table 1). Therefore, the cultivation of algae in wastewater offers the combined advantages of mitigation of greenhouse gases, treatment of the wastewaters, and simultaneously producing algal biomass. This biomass can be exploited for multiple uses-as protein supplements and food additives (animal and human feed), bioenergy resources (biogas and biofuels), bio-ore for precious heavy metals, pharmaceuticals, cosmetics and other valuable chemicals (Gupta et al. 2013; Pittman et al. 2011; Sahu et al. 2013; Singh et al. 2011; Spolaore et al. 2006).

This review is, therefore, an attempt to summarize the reports available on the diversity of microalgae in various wastewaters and critically evaluate their role in wastewater treatment, besides exploring the potential of wastewaters for efficient microalgae biomass production. Since, various microalgae differ in their nutrient sequestration ability and competitive potential in different wastewaters under natural environments, the significance of consortial approach is also discussed.

\section{Microalgal diversity in wastewater}

The release of industrial and municipal wastewater poses serious environmental challenges to the receiving water bodies (Yang et al. 2008). Wastewater is usually rich in contaminants in the form of nutrients, heavy metals, hydrocarbons etc. The presence of nutrients especially nitrogen $(\mathrm{N})$ and phosphorus $(\mathrm{P})$, in the form of nitrate, nitrite, ammonia/ammonium or phosphorus in wastewater leads to eutrophication (Liu et al. 2010; Yang et al. 2008). Microalgae represent an integral part of the microbial diversity of wastewaters, which can also play a role in the self-purification of these wastewaters (Sen et al. 2013).

Microalgae constitute a broad category of organisms encompassing photoautotrophic eukaryotic microalgae and prokaryotic cyanobacteria, which are distributed both in fresh and marine environments, with a wide range of diversity in their thallus organization and habitat (Lee 2008). The biodiversity of microalgae is enormous and estimated to be about 200,000-800,000 species, out of which about 50,000 species are only described (Starckx 2012). This enormous diversity and propensity to adapt to extreme and inhospitable habitats has led the scientific community to screen, identify promising strains/species/ genera and develop promising microalgae-based 


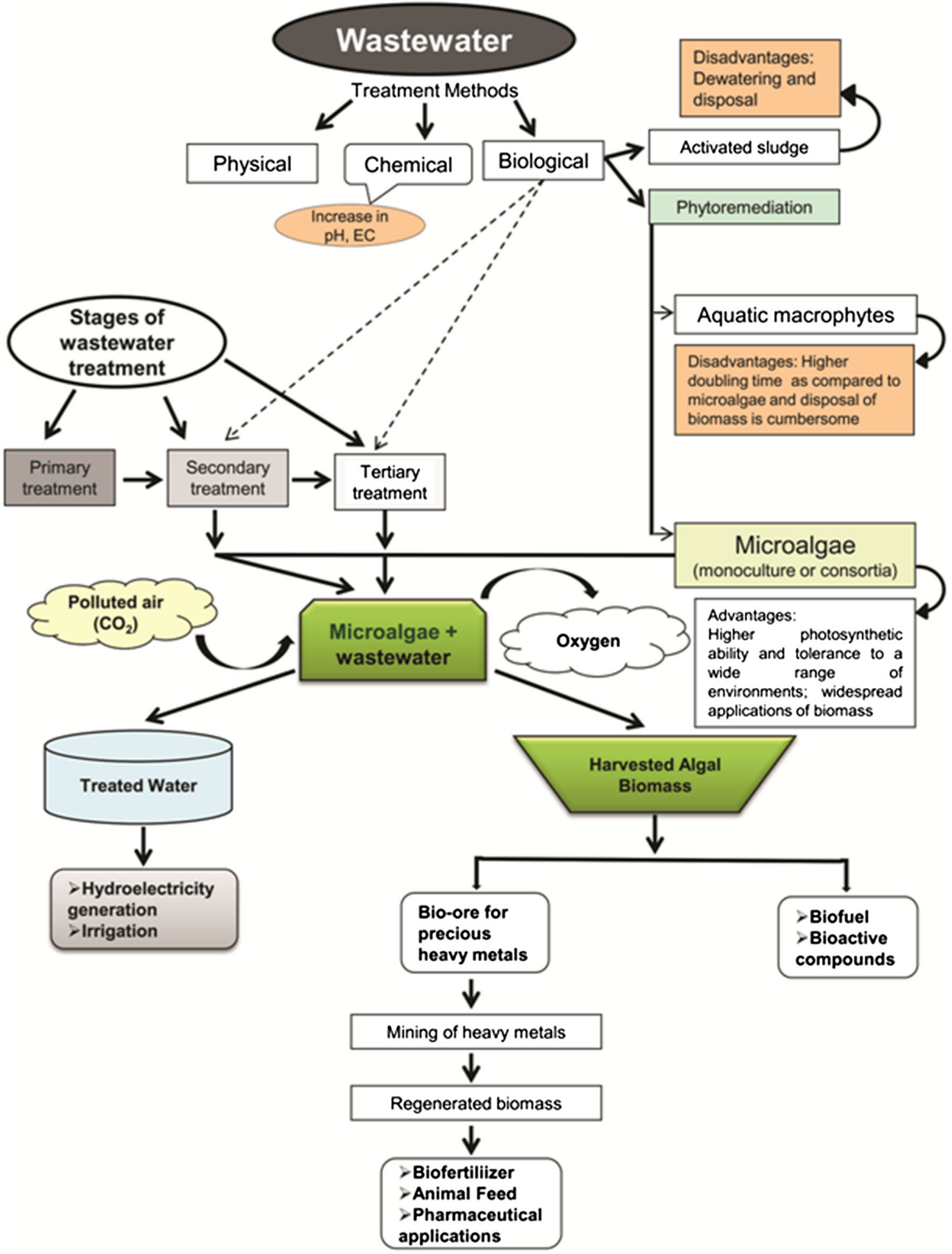

Fig. 1 Schematic representation of wastewater treatment using microalgae: overview of advantages and applications

technologies for wastewater treatment (Fouilland 2012). The available literature relevant in relation to research undertaken in terms of microalgal diversity in various types of wastewaters is summarized in Table 2.
Hussein and Gharib (2012) analyzed the phytoplankton diversity in sewage water mixed with drain water and observed a total of 152 taxa, including Bacillariophyceae (60), Chlorophyceae (20), Cyanophyceae (20), Euglenophyceae (17) and 
Table 1 Comparison of wastewater treatment potential of microalgae and higher aquatic macrophytes

\begin{tabular}{|c|c|c|}
\hline Characteristics & Microalgae & $\begin{array}{l}\text { Higher aquatic } \\
\text { macrophytes }\end{array}$ \\
\hline Doubling time & $\begin{array}{l}\text { Microalgae double their } \\
\text { biomass within } \\
\text { 1-2 days }\end{array}$ & $\begin{array}{l}\text { Much higher time is } \\
\text { required by aquatic } \\
\text { macrophytes to double } \\
\text { their biomass }\end{array}$ \\
\hline $\begin{array}{l}\mathrm{CO}_{2} \\
\text { sequestration } \\
\text { potential }\end{array}$ & $\begin{array}{l}\text { Much higher } \\
\text { photosynthetic } \\
\text { efficiency provides } \\
\text { them with relatively } \\
\text { higher } \mathrm{CO}_{2} \text { mitigation } \\
\text { potential. Therefore, } \\
\text { help in reduction of } \\
\text { greenhouse effect to } \\
\text { solve the problem of } \\
\text { global warming }\end{array}$ & $\begin{array}{l}\text { Relatively lower } \\
\text { photosynthetic } \\
\text { efficiency hence, } \\
\text { lower } \mathrm{CO}_{2} \text { mitigation } \\
\text { potential }\end{array}$ \\
\hline $\begin{array}{l}\text { Space } \\
\text { requirement }\end{array}$ & $\begin{array}{l}\text { Smaller dimensions } \\
\text { require less space for } \\
\text { the growth of } \\
\text { microalgae as } \\
\text { monoculture or } \\
\text { consortia }\end{array}$ & $\begin{array}{l}\text { Large size of } \\
\text { macrophytes require } \\
\text { more space for their } \\
\text { maintenance and } \\
\text { growth }\end{array}$ \\
\hline Processing & $\begin{array}{l}\text { Relatively easy to scale } \\
\text { up of process because } \\
\text { they can be harvested } \\
\text { with relative ease } \\
\text { (because of } \\
\text { filamentous nature or } \\
\text { flocculation ability) }\end{array}$ & $\begin{array}{l}\text { Difficult to scale up } \\
\text { process at commercial } \\
\text { levels because of } \\
\text { rooted nature of } \\
\text { macrophytes }\end{array}$ \\
\hline $\begin{array}{l}\text { Biomass } \\
\text { disposal and } \\
\text { its } \\
\text { applications }\end{array}$ & $\begin{array}{l}\text { Smaller size of } \\
\text { microalgae results in } \\
\text { easy disposal and } \\
\text { transport of biomass } \\
\text { for other } \\
\text { biotechnological } \\
\text { applications from their } \\
\text { site of production to } \\
\text { their utilization sites }\end{array}$ & $\begin{array}{l}\text { Lesser number of } \\
\text { applications of } \\
\text { biomass are explored } \\
\text { as their huge biomass } \\
\text { is difficult to dispose } \\
\text { and transport }\end{array}$ \\
\hline
\end{tabular}

Dinophyceae (9). Bacillariophyta was the dominant group, constituting $39.4 \%$ of overall diversity in the drain. However, in an open sewage-contaminated channel, Renuka et al. (2013a) observed the dominance $(58 \%)$ of Cyanophycean members comprising species of Chroococcus (Fig. 2a, b), Lyngbya (Fig. 2c) Phormidium (Fig. 2d), Limnothrix (Fig. 2e), Oscillatoria (Fig. 2f), and Planktothrix (Fig. 2g), followed by members of Chlorophyta (25\%) and Bacillariophyta $(17 \%)$. Bernal et al. (2008) studied the change in microalgal community in batch reactors of municipal wastewater treatment containing dairy sewage water and observed that microalgae from Cyanophyta, Chlorophyta and Euglenophyta groups were present during all the phases of the treatment process; Arthrospira jenneri (Cyanophyta) and Coccomonas sp. (Chlorophyta) were the most common members (Table 2).
In a study on the wastewater treatment plant (WWTP) at Shimoga Town, Karnataka State, India, seventy-one species belonging to Cyanophyceae, Chlorophyceae, Euglenophyceae, Bacillariophyceae and Desmidiaceae were recorded by Shanthala et al. (2009). Chlorella and Scenedesmus (Chlorophyta) were the dominant forms throughout the year, and the high pollution load was observed to have a negative impact on the total phytoplankton diversity. In another study from a wastewater stabilization pond, Furtado et al. (2009) isolated ten cyanobacterial genera as the dominant forms, including Synechococcus, Merismopedia, Leptolyngbya, Limnothrix and Nostoc, which represented more than $90 \%$ of the total phytoplankton diversity of waste stabilization pond, during the periods of summer and autumn (Table 2).

Cyanobacteria also constitute an important part of the phytoplankton diversity of WWTP, due to the existence of warm, stable and nutrient-enriched water (Badr et al. 2010; Martins et al. 2010; Vasconcelos and Pereira 2001). Vasconcelos and Pereira (2001) studied the phytoplankton communities of two ponds (facultative and maturation) of the WWTP of Esmoriz (North Portugal) and reported that cyanobacteria constitute $15.2-99.8 \%$ of the total phytoplankton diversity. Among these, Planktothrix mougeotii, Microcystis aeruginosa and Pseudoanabaena mucicola were the dominant species (Table 2). Similarly, in another report, Badr et al. (2010) noticed that cyanobacteria in facultative and maturation ponds of WWTP of El-Sadat city, Egypt constituted 2-97.8\% of the total phytoplankton density. Martins et al. (2010) isolated 51 strains of cyanobacteria belonging to Phormidium autumnale, Planktothrix mougeotii, Limnothrix sp. and Synechocystis sp. during a 12-month study from WWTP located in the north of Portugal. Ghosh and Love (2011) reported a high level of algal diversity comprising diatoms, green algae, cyanobacteria, Eustigmatophycean members, and unknown heterokonts using $r b c L$ gene as a marker, in a wastewater treatment plant situated at Tampa, Florida and Northfield, Michigan.

Apart from wastewater treatment plants, reports are also available on the distribution and diversity of microalgae in industrial effluents (Dubey et al. 2011; Vijayakumar et al. 2007). Vijayakumar et al. (2007) observed that among the different effluents studied, cyanobacterial species comprise $93 \%$ in sugar mill effluent, $91 \%$ in dye effluent, and 76 and $50 \%$ in paper mill and pharmaceutical effluents, respectively. In all these effluents, the cyanobacterial genus Oscillatoria was the dominant form, followed by Phormidium, Lyngbya, Microcystis and Synechococcus (Table 2). Dubey et al. (2011) recorded a total of 25 species of cyanobacteria in paper mill and pharmaceutical effluents. Microcystis aeruginosa, Oscillatoria curviceps, $O$. princeps, Phormidium ambiguum and 


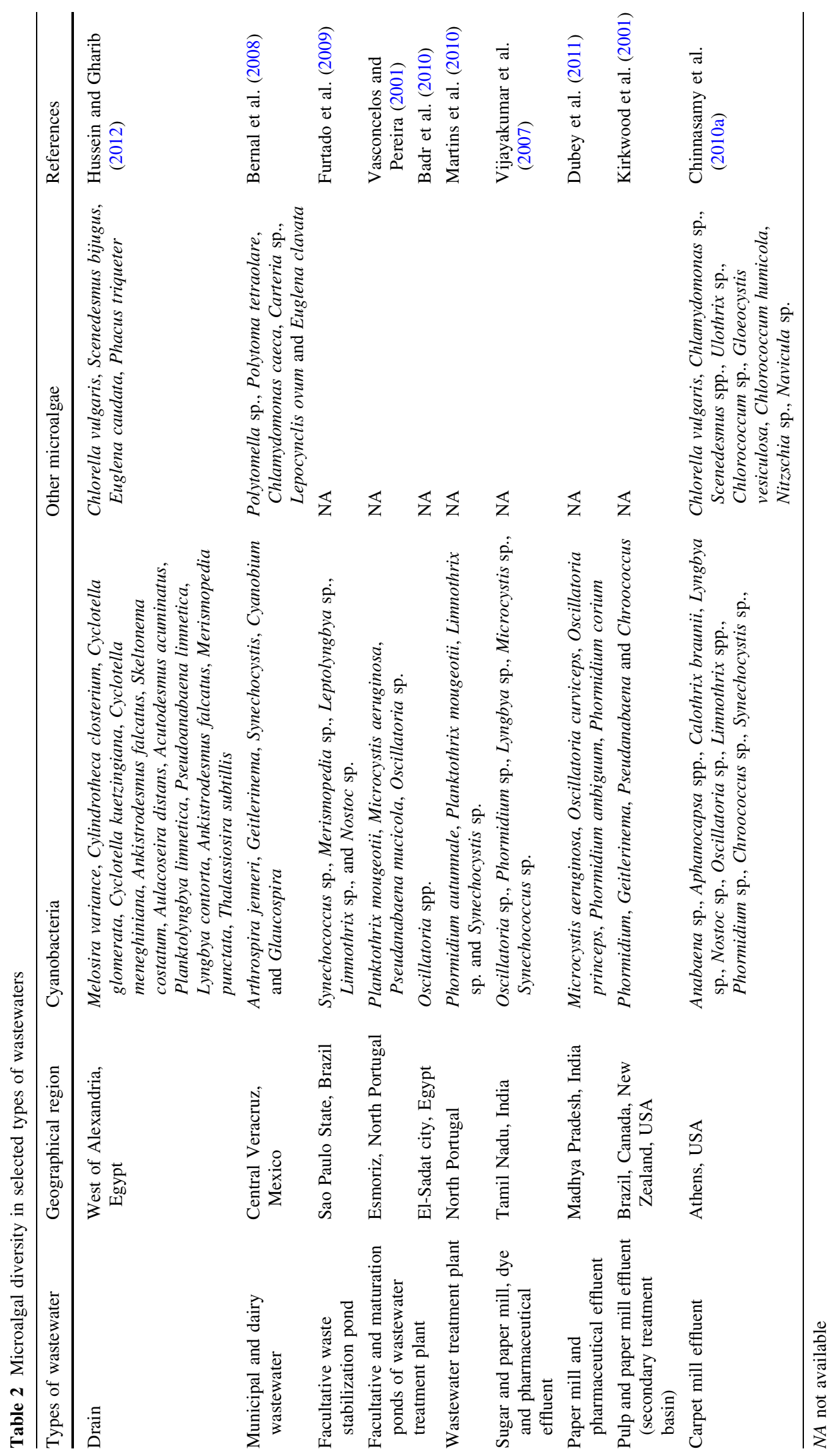



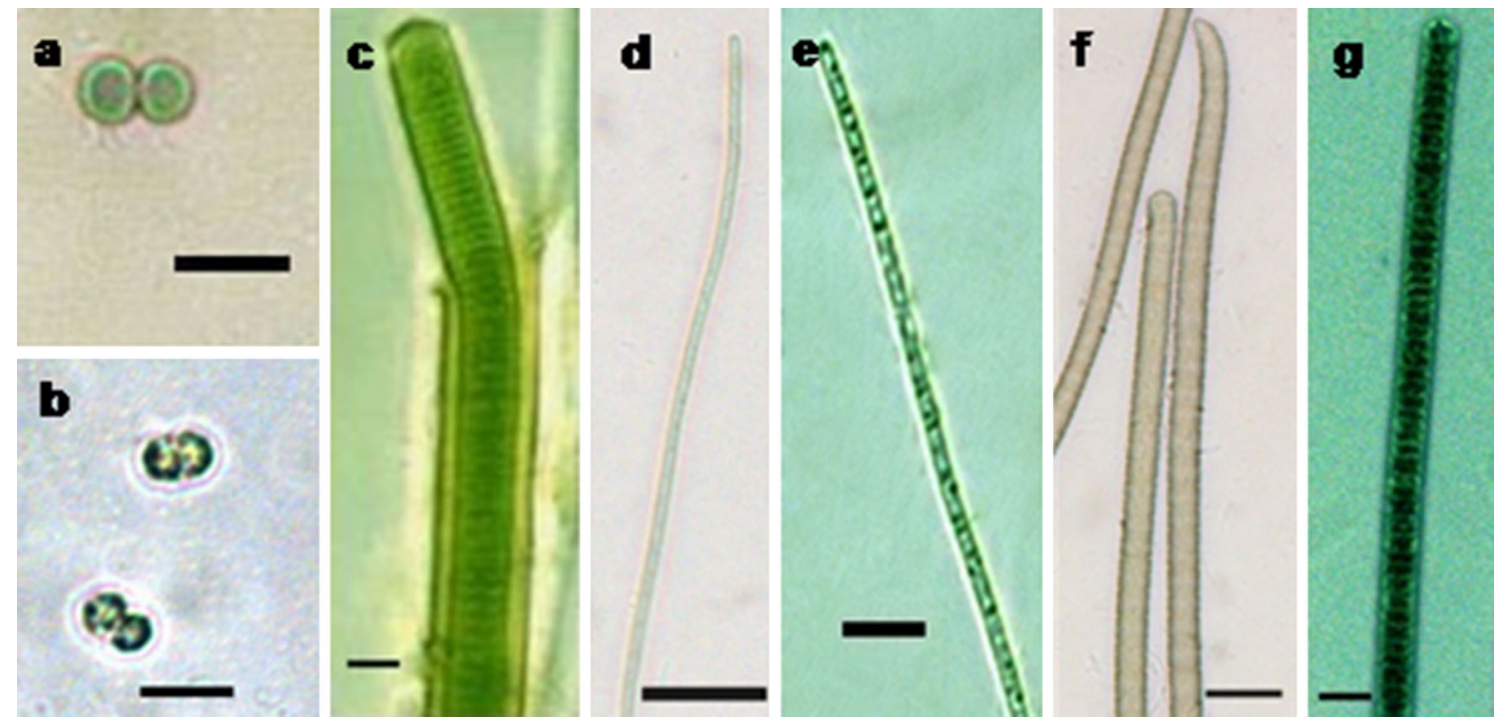

Fig. 2 Photomicrographs of dominant cyanobacterial genera commonly observed in wastewater. a, b Chroococcus sp. c Lyngbya sp. d Phormidium sp. e Limnothrix sp. f Oscillatoria sp. g Planktothrix sp. (scale bar $20 \mu \mathrm{m}$ )

P. corium were found to be common to both the effluents. They also observed Oscillatoria sp. as the most dominant genus. In another report, cyanobacterial communities belonging to Oscillatoriales and Chroococcales were found in the effluents of pulp and paper secondary wastetreatment systems of Brazil, Canada, New Zealand, and USA (Kirkwood et al. 2001); Phormidium, Geitlerinema, Pseudanabaena and Chroococcus were the dominant genera. Chinnasamy et al. (2010a) assessed the microalgal diversity of treated and untreated carpet mill effluent and observed more or less equal diversity of both Cyanophycean and Chlorophycean members in treated wastewater during spring season, whereas Chlorophyta was the dominant group in all the seasons in untreated wastewater (Table 2).

It is now documented that algae represent a significant biotic component of such aquatic ecosystems, showing a wide range of morphological and taxonomic diversity which is significantly influenced by composition and concentration of various contaminants present. Despite the availability of a large number of reports, the range of habitats, environmental conditions and diverse types of wastewaters makes it difficult to come out with generalizations regarding diversity, especially the factors contributing to the overall qualitative and quantitative aspects of microalgal diversity. However, the following points can be concluded from Table 2; these are (1) Cyanobacteria are predominant in most types of wastewaters, followed by green algal members, and (2) the critical factors seem to be environmental conditions or different geographical locations of study areas which need in-depth and long-term investigations.
Use of microalgal monocultures in nutrient sequestration and biomass production

The use of microalgae for the treatment of municipal wastewater has been a subject of research for several decades (Oswald 1988). Several microalgae are efficient in the removal of nutrients ( $\mathrm{N}$ and $\mathrm{P}$ ) from wastewater, and many species proliferate in wastewaters due to the abundance of carbon, nitrogen and phosphorus that serve as nutrients for their growth. However, the nutrient sequestration or wastewater treatment ability of microalgae differs across genera, species and strains. Many researchers have evaluated the potential of various microalgal monocultures for nutrient removal vis-a-vis biomass production in various types of wastewaters (Tables 3, 4). Since, wastewaters differ in their physicochemical characteristics, which directly or indirectly can have an effect on algal growth; it is difficult to provide any generalization regarding the quality and quantity of generated biomass. Therefore, it is important to first check the suitability of such wastewaters for the growth of microalgal monocultures, before they can be utilized at pilot scale for biotechnological applications and other downstream processes. Such studies on screening of individual microalgae (or microalgal monocultures) also help in deciphering the potential of individual strain vis-a-vis removal of specific or several nutrients.

\section{Use of municipal wastewater}

Municipal/domestic wastewaters are usually rich in nutrients, mainly, nitrogen and phosphorus; enough information 


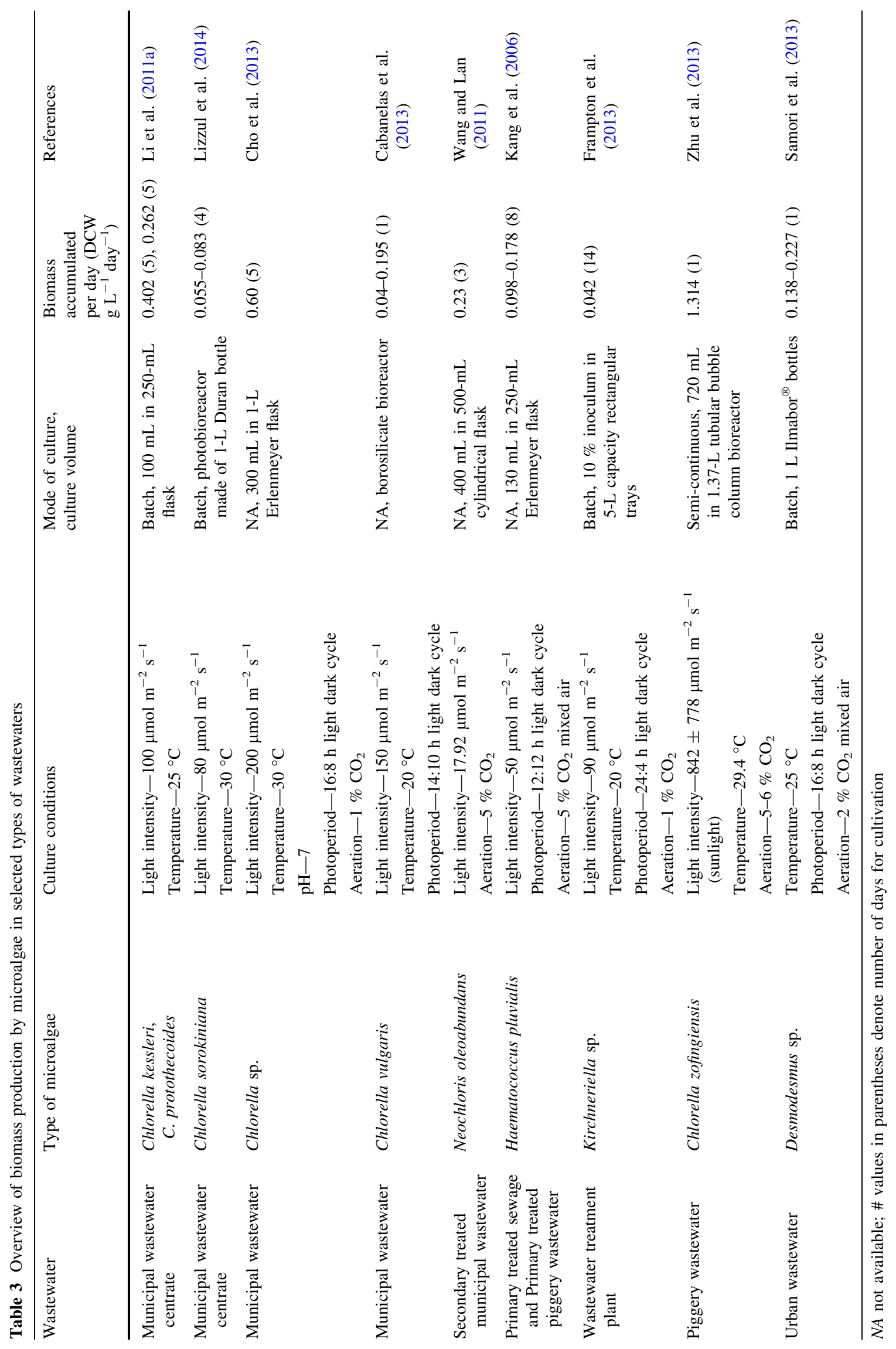




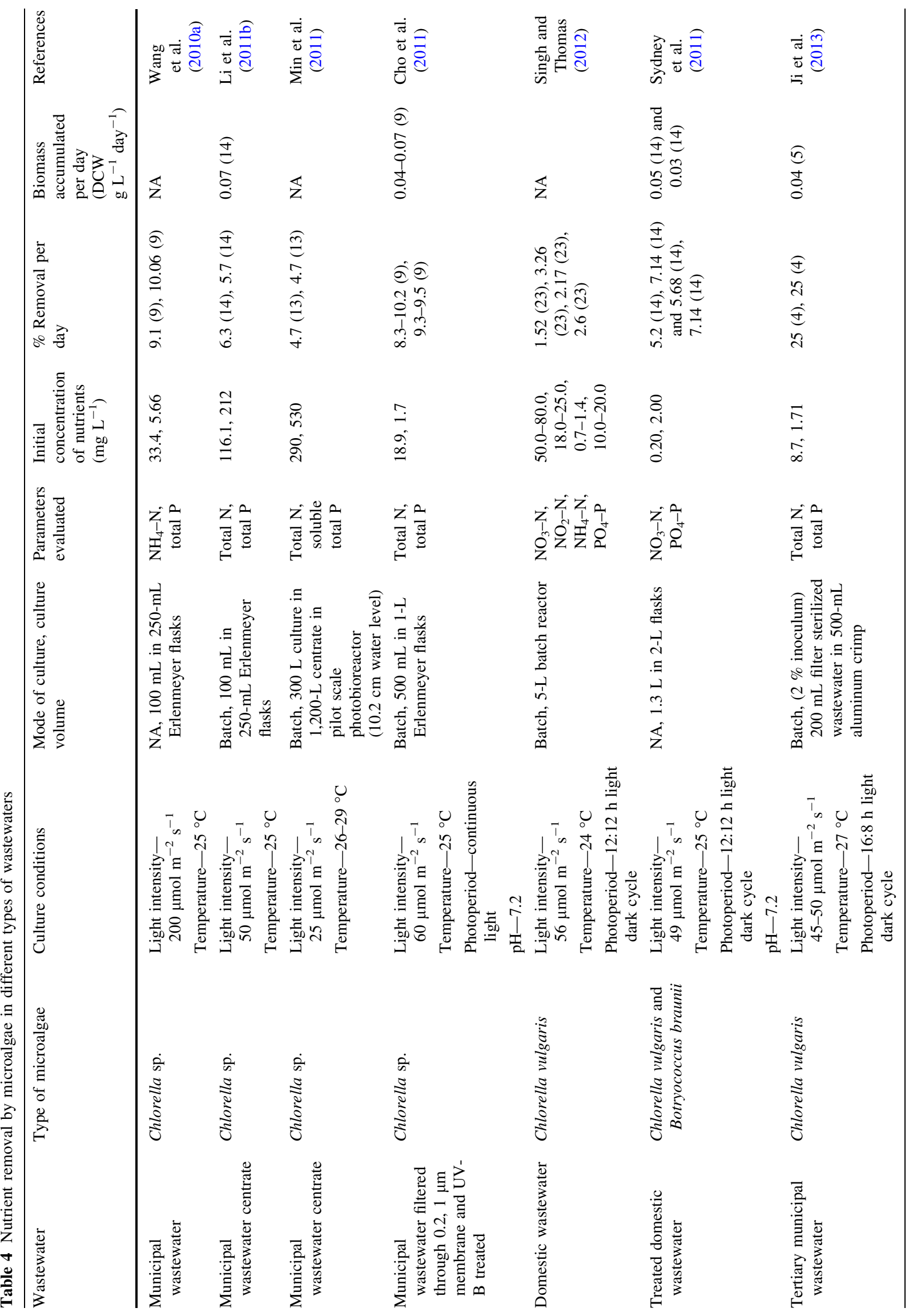




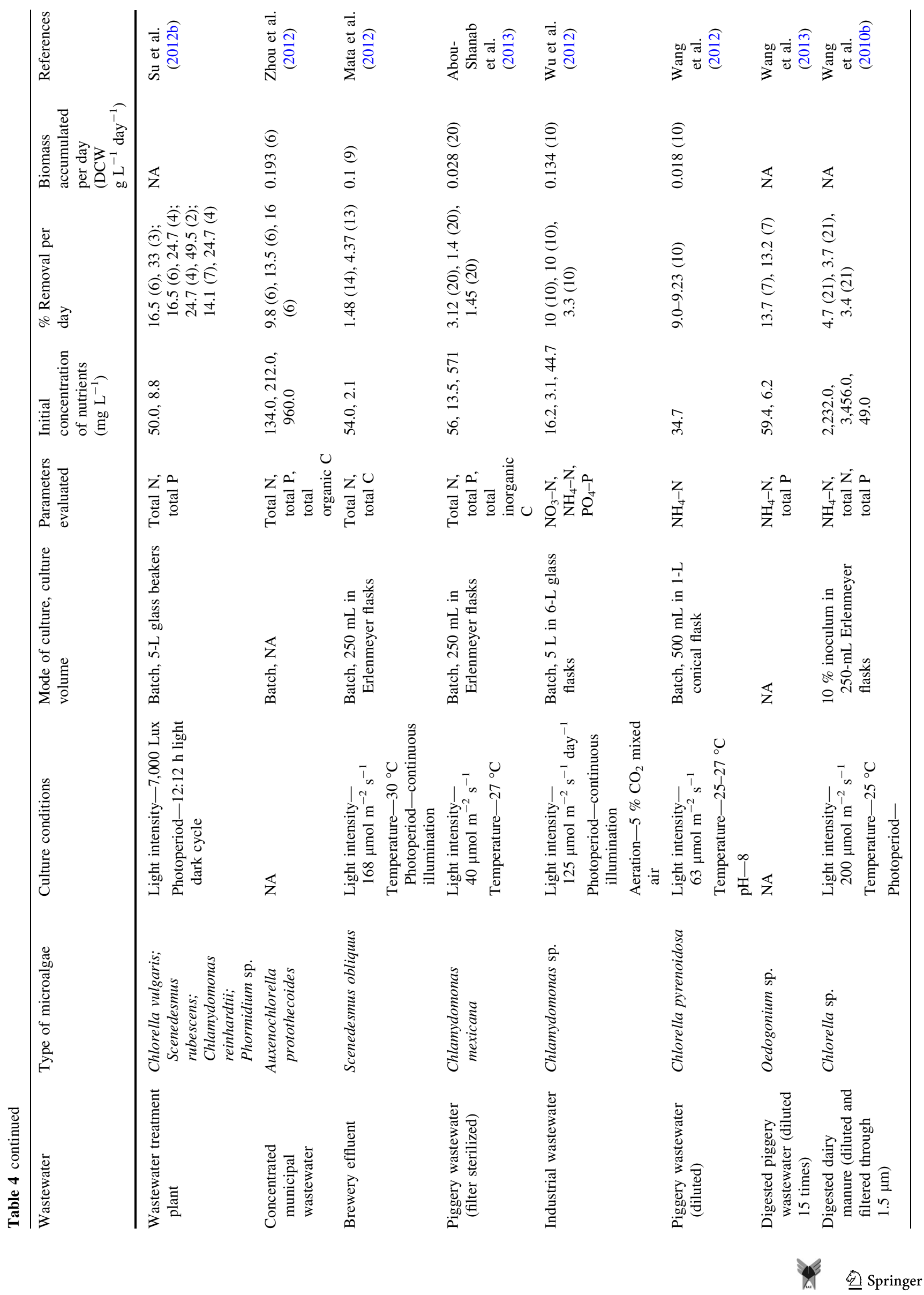




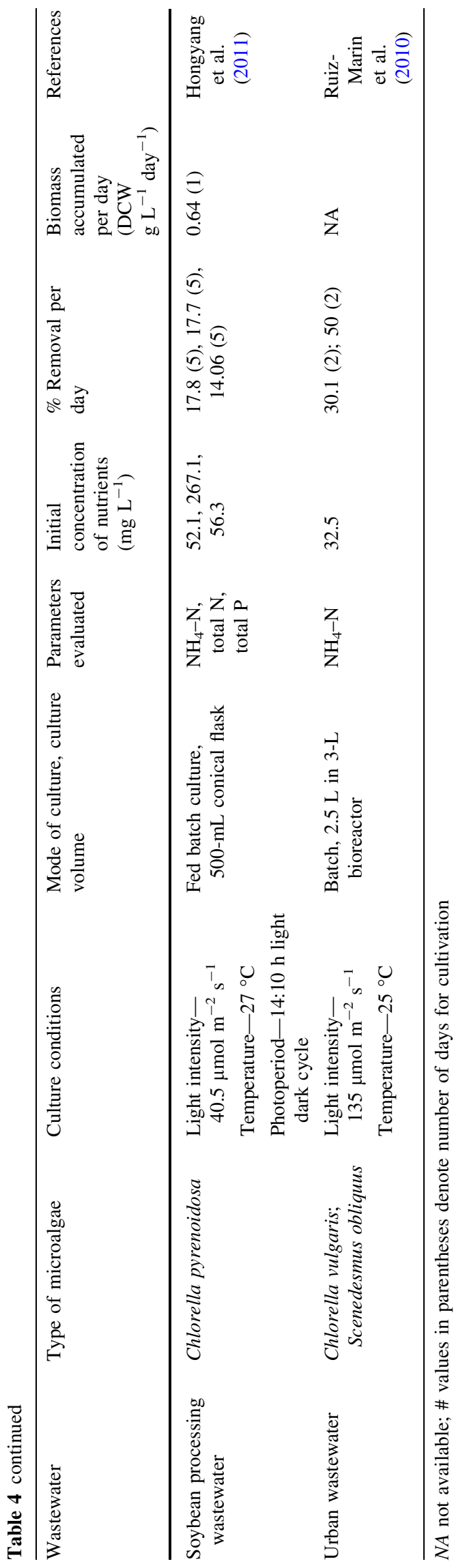

is available on the utilization of these wastewaters as alternative growth media for microalgae (Bhatnagar et al. 2011; Frampton et al. 2013; Mutanda et al. 2011). Table 3 summarizes the reports on microalgal biomass production in different types of wastewater.

Li et al. (2011a) studied the growth potential of Chlorella kessleri and $C$. protothecoides in municipal wastewater centrate. The maximum biomass of 2.01 and $1.31 \mathrm{~g} \mathrm{~L}^{-1}$ was obtained in 5 days from C. kessleri and C. protothecoides, respectively, and both strains also showed the ability to grow mixotrophically in centrate (Table 3). Bhatnagar et al. (2010) revealed that C. minutissima can grow heterotrophically in dark acidic conditions and mixotrophically over a range of organic carbon substrates in municipal wastewater. Secondary treated municipal wastewater can be used as cultivation medium for Neochloris oleoabundans (Wang and Lan 2011). This alga produced 2.1 and $0.68 \mathrm{~g} \mathrm{~L}^{-1}$ biomass, when grown in secondary treated municipal wastewater supplemented with $70 \mathrm{mg} \mathrm{N} \mathrm{L}^{-1}$ and without N, respectively (Table 3). Kang et al. (2006) reported that Haematococcus pluvialis produced $0.78 \mathrm{~g} \mathrm{~L}^{-1}$ biomass on primary treated sewage. Frampton et al. (2013) observed that Kirchneriella sp. was able to produce $0.60 \mathrm{~g} \mathrm{~L}^{-1}$ biomass in 14 days on wastewater collected from WWTP. Interestingly, biomass production of $3.01 \mathrm{~g} \mathrm{~L}^{-1}$ was obtained by growing Chlorella sp. in combined wastewater from digestion tank and dewatering facility (10:90 v/v, respectively) collected from WWTP at Busan, Korea, was 1.72 times higher than that with standard BG-11 medium (Cho et al. 2013). Recently, Samori et al. (2013) were able to grow Desmodesmus sp. in $\mathrm{CO}_{2}$-enriched urban wastewater and biomass productivity ranging from 0.138 to $0.227 \mathrm{~g} \mathrm{~L}^{-1}$ day $^{-1}$ was recorded (Table 3). Lizzul et al. (2014) observed that Chlorella sorokiniana produced $0.22 \mathrm{~g} \mathrm{~L}^{-1}$ of biomass in municipal wastewater centrate and supplementation of external $\mathrm{CO}_{2}$ increased biomass production to $0.33 \mathrm{~g} \mathrm{~L}^{-1}$.

The reports dealing with nutrient removal potential and biomass production in wastewaters are summarized in Table 4. Wang et al. (2010a) evaluated the nutrient removal efficiency of Chlorella sp. in wastewater samples collected at different points of WWTP. Highest $\mathrm{NH}_{4}-\mathrm{N}$ removal of $82.4 \%$ was observed in wastewater collected before primary settling, while highest $\mathrm{PO}_{4}-\mathrm{P}$ removal of $90.6 \%$ was observed in wastewater after primary settling. Chlorella sp. was able to remove 83.2 and $85.6 \%$ of phosphorus from the wastewater before primary settling and centrate, respectively. Min et al. (2011) also found that Chlorella sp. was able to remove both nitrogen (61\%) and phosphorus $(61 \%)$ from the municipal centrate (Table 4). Li et al. (2011b) recorded that Chlorella sp. removed 93.9, 89.1 and $80.9 \%$ of $\mathrm{NH}_{4}-\mathrm{N}$, total $\mathrm{N}$ and $\mathrm{P}$, respectively, and produced $0.92 \mathrm{~g} \mathrm{~L}^{-1}$ of biomass per day on raw 
municipal wastewater centrate. In an another report, Cabanelas et al. (2013) reported the highest productivity $\left(0.195 \mathrm{~g} \mathrm{~L}^{-1} \mathrm{day}^{-1}\right)$ and nutrient removal $(\mathrm{N}-$ $9.8 \mathrm{mg} \mathrm{L}^{-1} \mathrm{day}^{-1}$ and $\mathrm{P}-3 \mathrm{mg} \mathrm{L}^{-1} \mathrm{day}^{-1}$ ) rates of Chlorella $\mathrm{sp}$. in wastewater from WWTP with N/P ratio of 2 . Kim et al. (2010) observed a $50 \%$ decrease in $\mathrm{NH}_{4}-\mathrm{N}$ concentration by Chlorella vulgaris in $48 \mathrm{~h}$, when grown in raw wastewater effluent. Cho et al. (2011) studied the effect of different pre-treatments-filtration $(0.45-\mu \mathrm{m}$ pore-size filter) and UV treatments (over $1,620 \mathrm{~mJ} \mathrm{~cm}^{-2}$ ) on the nutrient removal ability of Chlorella sp. They reported that Chlorella removed 85, 92 and $74 \%$ of total N and 84,86 and $84 \%$ of total P, respectively, from secondary treated municipal wastewater filtered with $0.2-\mu \mathrm{m}$ membrane, $1-\mu \mathrm{m}$ membrane or UV-B dose, respectively. The highest biomass of $0.67 \mathrm{~g} \mathrm{~L}^{-1}$ was produced by Chlorella sp. grown in filtered secondary wastewater $(0.2 \mu \mathrm{m}$ followed by $1-\mu \mathrm{m}$ membrane) and UV dose $(0.41$ and $0.5 \mathrm{~g} \mathrm{~L}^{-1}$, respectively).

Singh and Thomas (2012) compared the nutrient removal potential of different microalgae-Chlorella sp., C. vulgaris, Scenedesmus quadricauda and S. dimorphus as monocultures in permeate from aerobic membrane bioreactor fed with domestic wastewater. Among different microalgae, $C$. vulgaris was able to remove $35,75,50$ and $60 \%$ of $\mathrm{NO}_{3}-\mathrm{N}, \mathrm{NO}_{2}-\mathrm{N}, \mathrm{NH}_{4}-\mathrm{N}$ and $\mathrm{PO}_{4}-\mathrm{P}$, respectively, after 23 days in continuous aerobic membrane bioreactor (microalgae membrane bioreactor). However, all four microalgae were able to remove $100 \%$ of $\mathrm{NH}_{4}-\mathrm{N}$ and 43-54, 83-95 and 70-92\% of $\mathrm{NO}_{3}-\mathrm{N}, \mathrm{NO}_{2}-\mathrm{N}$ and $\mathrm{PO}_{4}-\mathrm{P}$, respectively, after 3 days in the batch reactor (Table 4). Ji et al. (2013) studied the biomass production and nutrient removal potential of Chlorella vulgaris, Scenedesmus obliquus and Ourococcus multisporus in tertiary treated municipal wastewater. All the studied microalgae removed more than $99 \%$ of the nitrogen and phosphorus in 4 days. Biomass production of $0.197 \mathrm{~g} \mathrm{~L}^{-1}$ was obtained by Chlorella vulgaris, Scenedesmus obliquus, while Ourococcus multisporus accounted for $0.203 \mathrm{~g} \mathrm{~L}^{-1}$ of biomass in tertiary wastewater effluent ( $\mathrm{Ji}$ et al. 2013).

Nutrient removal potential of 13 microalgal strains in treated domestic wastewater was determined by Sydney et al. (2011). They reported that Botryococcus braunii removed $79.63 \%$ of the nitrogen and $100 \%$ phosphorus from treated domestic wastewater in 14 days. Su et al. (2012b) observed that Phormidium sp., Chlamydomonas reinhardtii, Chlorella vulgaris and Scenedesmus rubescens removed $99 \%$ of total $\mathrm{N}$ within 7, 4, 6 and 6 days, and $\mathrm{P}$ in 4, 2, 3 and 4 days, respectively, from the effluent collected from wastewater treatment plant of Holthusen, Germany. Zhou et al. (2012) reported that Auxenochlorella protothecoides was able to remove 59,81 and $96 \%$ of total N, P and $\mathrm{C}$, respectively, when grown in concentrated municipal wastewater for 6 days. This microalga produced $1.16 \mathrm{~g} \mathrm{~L}^{-1}$ of biomass in 6 days in the same medium (Table 4).

\section{Other wastewaters}

Apart from municipal wastewater, Kang et al. (2006) reported that Haematococcus pluvialis can also produce $1.43 \mathrm{~g} \mathrm{~L}^{-1}$ biomass, when grown in diluted (fourfold) primary piggery wastewater (Table 3 ). Zhu et al. (2013) recorded biomass productivity of $1.314 \mathrm{~g} \mathrm{~L}^{-1}$ day ${ }^{-1}$ by cultivating Chlorella zofingiensis in piggery wastewater pre-treated with sodium hypochlorite $(\mathrm{NaClO})$. Ryu et al. (2013) found a biomass productivity of $6.69 \mathrm{~g} \mathrm{~L}^{-1} \mathrm{day}^{-1}$ for Aurantiochytrium sp., using spent yeast from brewery industry as the growth substrate, with simple stirring as pre-treatment.

Mata et al. (2012) studied the growth and wastewater treatment potential of Scenedesmus obliquus in brewery effluent. The alga was able to remove $20.8 \%$ of total $\mathrm{N}$ and $56.9 \%$ of total carbon in 9 and 13 days, respectively. This microalga produced $0.9 \mathrm{~g} \mathrm{~L}^{-1}$ of biomass in 9 days (Table 4). Abou-Shanab et al. (2013) screened different microalgal strains viz. Ourococcus multisporus, Nitzschia cf. pusilla, Chlamydomonas mexicana, Scenedesmus obliquus, Chlorella vulgaris, and Micractinium reisseri for nutrient removal and biomass production in piggery wastewater. Highest removal of total N, P and inorganic C of 62,28 and $29 \%$ was obtained by C. mexicana. This alga also produced highest dry biomass of $0.56 \mathrm{~g} \mathrm{~L}^{-1}$ compared to other microalgae grown in piggery wastewater for 20 days. Chlamydomonas sp. removed $100 \%$ of $\mathrm{NO}_{3}-\mathrm{N}$, $\mathrm{NH}_{3}-\mathrm{N}$ and $33 \% \mathrm{PO}_{4}-\mathrm{P}$ and produced $1.34 \mathrm{~g} \mathrm{~L}^{-1}$ biomass from the industrial effluent in 10 days (Wu et al. 2012). In an another report by Lim et al. (2010), Chlorella vulgaris removed $45.1 \%$ of $\mathrm{NH}_{4}-\mathrm{N}, 33.3 \% \mathrm{PO}_{4}-\mathrm{P}$ and produced $0.107 \mathrm{~g} \mathrm{~L}^{-1}$ biomass in textile wastewater. They observed that the addition of nutrients of Bold's Basal medium to textile wastewater increased the biomass production to $0.613 \mathrm{~g} \mathrm{~L}^{-1}$, however, did not improve the removal of nutrients. Ruiz-Marin et al. (2010) compared the $\mathrm{N}$ and $\mathrm{P}$ removal ability of immobilized and free cells of Chlorella vulgaris and Scenedesmus obliquus, and found that $S$. obliquus had a higher $\mathrm{N}$ and $\mathrm{P}$ uptake in urban wastewater than Chlorella vulgaris. However, S. obliquus can be more effective in nutrient removal when immobilized with the recalcification of beads than free cell cultures (Table 4). Free cells of Chlorella vulgaris can remove $60.1 \%$ of ammonia in $48 \mathrm{~h}$ in urban wastewater, while $100 \%$ of ammonia removal was observed with Scenedesmus obliquus in the same time duration. Gonzalez et al. (2008) reported that Chlorella sorokiniana culture mixed with activated sludge removed 86 and $87 \%$ of total 
organic carbon and $\mathrm{NH}_{4}-\mathrm{N}$ from four times diluted pretreated piggery wastewater.

From these studies (Tables 3, 4), it can be summarized that Chlorella is the most explored microalga for the removal of nutrients ( $\mathrm{N}$ and $\mathrm{P}$ ) from different types of wastewaters and biomass production. A huge variation in the percent removal of nutrients with Chlorella spp. has been observed in the published literature (Tables 3, 4). Biomass productivity of $0.03-1.314 \mathrm{~g} \mathrm{~L}^{-1}$ day $^{-1}$ was recorded using various Chlorella spp. Highest biomass productivity of $1.314 \mathrm{~g} \mathrm{~L}^{-1} \mathrm{day}^{-1}$ was obtained from Chlorella zofingiensis grown in sunlight, in a bioreactor running in semi-continuous mode supplied with 5-6\% $\mathrm{CO}_{2}$ in piggery wastewater (Table 3 ). The observed variation in the nutrient removal potential and biomass productivity of various microalgal species can be attributed to not only the differences in the culture conditions (viz. light intensity, temperature, photoperiod, mode of culture) but also the type of wastewater used. The composition and concentration of nutrients and other harmful contaminants present in the wastewaters, the habitat of the strain, nature (biochemical attributes or genetic potential) of strain/species used are other important factors.

Despite many recent reports on utilization of microalgae in wastewater treatment and biomass generation, the problems related to harvesting of unicellular, monocultures of microalgae due to their microscopic dimensions have restricted its commercialization. Therefore, filamentous forms (with comparatively large dimensions) or consortial approach are being explored as more viable options to reduce the overall cost of the process and obtain better harvesting rates.

Significance and promise of consortial approach

No organism can sustain in totality in any ecosystem, as is illustrated by the above studies in which the monoculture of different microalgae need to compete with the indigenous microflora present in different wastewaters, which in turn, play a critical role in the overall biomass production and wastewater treatment potential (Bernal et al. 2008; Renuka et al. 2013a). Therefore, it can be envisaged that the use of consortia can be a promising alternative to increase the efficiency of process either for biomass production or wastewater treatment (Chinnasamy et al. 2010a; Mustafa et al. 2012). However, interactions among partners and sustainability of non-native microalgae in consortial approach are the major points of concern. In consortia, one strain of microalga may be efficient in removing one type of contaminant, and the other strain can be more effective in the uptake of another (Chinnasamy et al. 2010a). Hence, the development of consortia using promising strains can help to resolve not only the problem of their harmonious growth under unfavorable environments, but also prove synergistic and more effective in treating the wastewater in totality. Therefore, evaluation of the efficiency of native/ non-native consortia either for biomass production or wastewater treatment can be promising aspects for further research in this area.

\section{Wastewater treatment using microalgal consortia}

The reports on wastewater treatment and biomass production by microalgal consortia are summarized in Table 5 .

\section{Municipal wastewater}

Ruiz-Martinez et al. (2012) observed that the mixed microalgae (Chlorococcales and Cyanobacteria) isolated from the walls of the secondary clarifier in Carraixet WWTP grown in effluent of a submerged anaerobic bioreactor removed $67.2 \% \mathrm{NH}_{4}-\mathrm{N}$ and $97.8 \%$ of $\mathrm{PO}_{4}-\mathrm{P}$ in 42-day cultivation period and produced $0.234 \mathrm{~g} \mathrm{~L}^{-1} \mathrm{day}^{-1}$ biomass. Silva-Benavides and Torzillo (2011) compared the nutrient removal by Chlorella and Chlorella-Planktothrix co-cultures grown in municipal wastewater. Chlorella sp. was able to remove $100 \%$ of $\mathrm{PO}_{4}-\mathrm{P}$ in 2 days when grown as monoculture or co-culture with Planktothrix. However, about $80 \%$ (highest) removal of nitrogen can be obtained with unshaken co-culture of Chlorella and Planktothrix from municipal wastewater (Table 5). Renuka et al. (2013b) compared the potential of consortia of native filamentous strains, native unicellular strains and selected non-native microalgae for nutrient removal potential, water quality improvement and biomass production using primary treated sewage water. This study revealed that the consortium of filamentous isolates from primary treated sewage water proved most promising in nutrient removal efficiency, and also led to higher biomass production, as compared to the other consortia employed. The consortium of filamentous strains removed 90,100 and $97 \%$ of $\mathrm{NO}_{3}-$ $\mathrm{N}, \mathrm{NH}_{4}-\mathrm{N}$ and $\mathrm{PO}_{4}-\mathrm{P}$, and produced $1.07 \mathrm{~g} \mathrm{~L}^{-1}$ biomass on 10th and 6th day, respectively, in the sewage wastewater.

\section{Other wastewaters}

Singh et al. (2011) found that the consortium of Chlorella minutissima, C. sorokiniana and Scenedesmus bijuga produced $0.371 \mathrm{~g} \mathrm{~L}^{-1}$ biomass in $6 \%$ poultry litter effluent. They suggested that mixotrophic algae can prove to be suitable candidates for large-scale wastewater treatment, with concomitant production of renewable feedstock for animal feed and bioenergy applications. In an another report, Bhatnagar et al. (2011) studied the growth potential of combinations of different native strains of green 


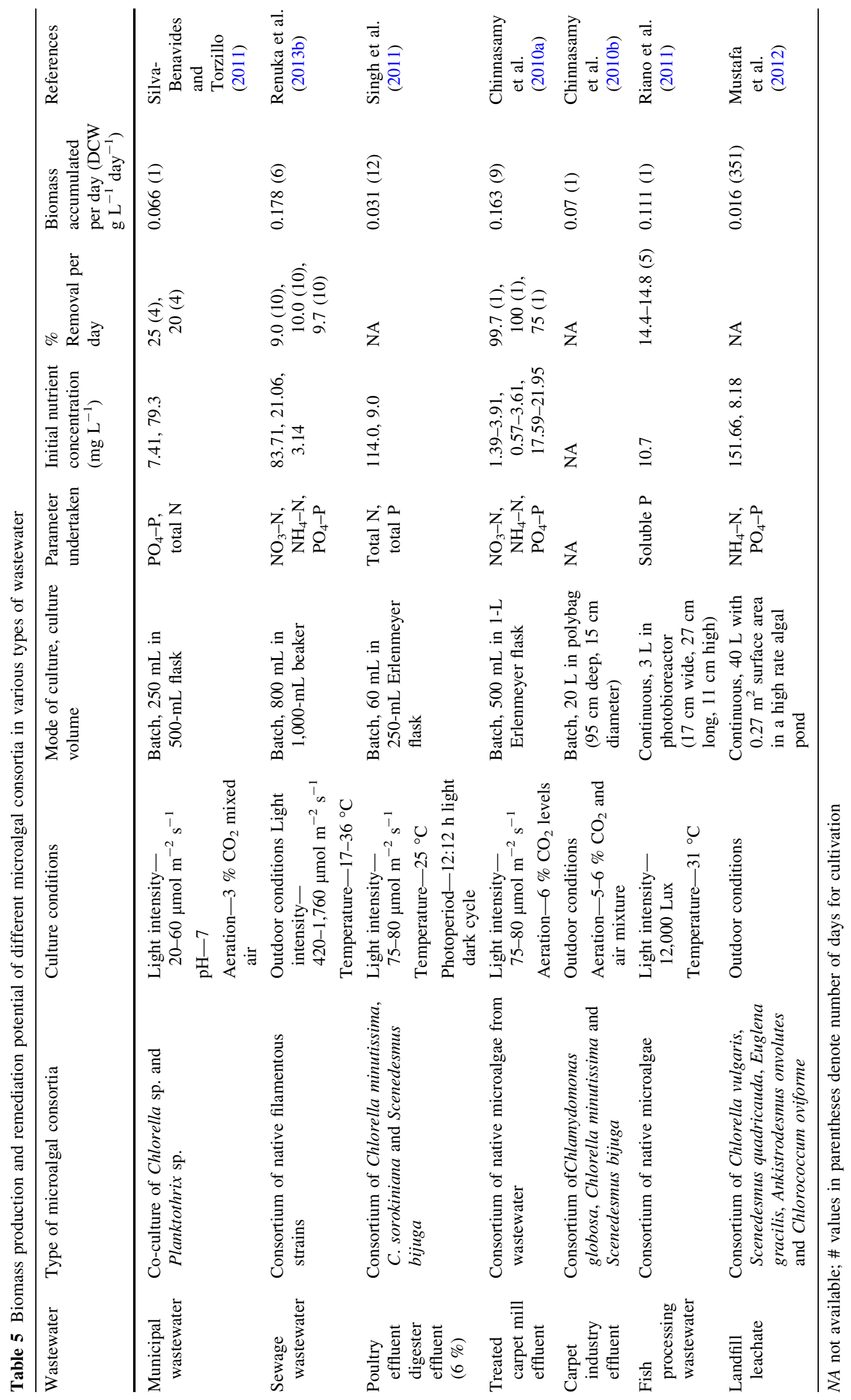


microalgae Chlamydomonas globosa, Chlorella minutissima and Scenedesmus bijuga in various types of industrial wastewaters such as-poultry litter extract, treated and untreated carpet mill effluent. They concluded that microalgae gown in poultry litter extract produced higher biomass compared with the standard growth medium BG 11 . They recorded highest biomass production of $0.349 \mathrm{~g} \mathrm{~L}^{-1}$ in poultry litter extract and $0.366 \mathrm{~g} \mathrm{~L}^{-1}$ in untreated carpet mill wastewater with mixture of Scenedesmus bijugaChlorella minutissima culture. However, under mixotrophic conditions, the algal consortium of Chlorella globosa-Chlorella minutissima and Scenedesmus bijugaChlorella minutissima generated higher biomass (3.017 and $1.655 \mathrm{~g} \mathrm{~L}^{-1}$, respectively) in poultry litter extract and carpet wastewater, respectively. Chinnasamy et al. (2010a) observed higher growth rate and nutrient removal by the consortium of 15 native algal strains isolated from carpet mill effluent, and reported better performance of consortium in the treated wastewater, despite the low concentration of nitrogen and phosphorus. They reported removal to the tune of 99, 100 and $75 \%$ of $\mathrm{NO}_{3}-\mathrm{N}, \mathrm{NH}_{4}-\mathrm{N}$ and $\mathrm{PO}_{4}-$ $\mathrm{P}$ in the first $24 \mathrm{~h}$, respectively, when supplied with $6 \%$ $\mathrm{CO}_{2}$-enriched air at $25{ }^{\circ} \mathrm{C}$. The consortium was able to produce $1.47 \mathrm{~g} \mathrm{~L}^{-1}$ biomass in 9 days. Biomass productivity of $0.07 \mathrm{~g} \mathrm{~L}^{-1}$ day $^{-1}$ was obtained by cultivating the consortium of Chlamydomonas globosa, Chlorella minutissima and Scenedesmus bijuga in polybags with untreated carpet industry effluent (Chinnasamy et al. 2010b). In another study, a consortium of microalgae isolated from a lagoon containing aerobically treated swine slurry was helpful in the efficient removal of nutrient from fish processing wastewater, recording $70 \%$ removal of phosphate from the wastewater and biomass productivity of $0.111 \mathrm{~g} \mathrm{~L}^{-1} \mathrm{day}^{-1}$ was achieved (Riano et al. 2011). Microalgal consortium of five microalgae viz. Chlorella vulgaris, Scenedesmus quadricauda, Euglena gracilis, Ankistrodesmus convolutus and Chlorococcum oviforme was able to remove 99.9 and $86 \%$ of $\mathrm{NH}_{4}-\mathrm{N}$ and $\mathrm{PO}_{4}-\mathrm{P}$ from landfill leachate, when grown in high rate algal pond, producing biomass of $5.54 \mathrm{~g} \mathrm{~L}^{-1}$ (Mustafa et al. 2012).

The comparison between the nutrient removal potential and biomass productivity of different monocultures and microalgal consortia used in various studies revealed a higher nutrient removal rate in microalgal consortia inoculated wastewater as compared to monocultures (Table 3, 4,5 ). Highest $\mathrm{NO}_{3}-\mathrm{N}, \mathrm{NH}_{4}-\mathrm{N}$ and $\mathrm{PO}_{4}-\mathrm{P}$ removal of 99.7 , 100 and $75 \%$, respectively, within $24 \mathrm{~h}$ was recorded from a consortium of native strains grown under batch mode with $6 \% \mathrm{CO}_{2}$ supply in treated carpet mill effluent (Table 5). Higher nutrient removal rate in microalgal consortia inoculated wastewaters could be due to the fact that the one microalgal strain can have high potential for removing one type of nutrient efficiently, while the other strain can be more effective in the uptake of another. This reveals a synergistic effect in the uptake of nutrients in consortial approach. However, the biomass productivities in batch cultures were comparable in monocultures and microalgal consortia grown under different and/or close culture conditions (Tables 3, 4, 5), and sometimes lower in consortial approach. The biomass productivities of $0.03-0.60$ and $0.03-0.178 \mathrm{~g} \mathrm{~L}^{-1} \mathrm{day}^{-1}$ were obtained in monocultures and microalgal consortia, respectively, grown in wastewater under batch mode in different investigations (Tables 3, 4, 5). Higher biomass productivity was observed in continuous and/or semi-continuous mode, as compared to batch mode of culture using monocultures (Tables 3, 4). In consortial approach, however, the biomass productivities did not differ significantly (Tables 3, 4, 5). Therefore, this area needs in-depth research regarding the interactions among the consortial members in order to enhance biomass productivity and nutrient removal.

Heavy metal removal by microalgae in wastewater

The presence of heavy metals and other compounds viz. phenols and detergents (Aonghusa and Gray 2002; Petrovic et al. 2003; Wang et al. 2010a) in municipal wastewater along with the nutrients is a matter of concern, because microalgae can sequester these compounds (Mani and Kumar 2014; Nacorda et al. 2007; Richards and Mullins 2013; Wang et al. 2010a). These heavy metals interfere with the uptake of macronutrients, as a result of common transporters (Levy et al. 2005; Thiel 1988). However, if present in trace amounts, some of these metals $(\mathrm{Cu}, \mathrm{Cd}, \mathrm{Pb}$ etc.) may act as micronutrients for the growing microalgae. Therefore, complete knowledge of wastewater characteristics is essential before using them as cultivation media for microalgae (Renuka et al. 2014). Apart from this, the cultivation of microalgae in heavy metals contaminated wastewaters proves problematic for the applications of biomass for food grade purposes e.g., feed, pharmaceuticals; however, the generated biomass can be used for such applications after the retrieval of heavy metals from biomass.

Ajayan et al. (2011) observed the highest $\mathrm{Cu}, \mathrm{Zn}$ and $\mathrm{Co}$ removal of $60,42.9$ and $29.6 \%$, respectively, with $O s$ cillatoria quadripunctutata, while highest $\mathrm{Pb}$ removal of $34.6 \%$ was observed with Scenedesmus bijuga in sewage wastewater. In another report, Chlorella sp. removed 65.4, 95.4, 98.3, 80, 98.2 and 56.5\% of $\mathrm{Al}, \mathrm{Ca}, \mathrm{Fe}, \mathrm{Mg}, \mathrm{Mn}$ and $\mathrm{Zn}$, respectively, from municipal wastewater (Wang et al. 2010a). El-Sheekh et al. (2005) also studied the removal of heavy metals from Verta Company, involved in paper production, sewage wastewater and salt and soda company wastewater by Nostoc muscorum, Anabaena subcylindrica 
and mixed culture of Nostoc muscorum and Anabaena subcylindrica and found significant removal of heavy metals from all types of wastewaters using microalgae. Monocultures of Nostoc muscorum and Anabaena subcylindrica were able to remove $64.4,22.20,84.6$ and $64.10 \%$ and $33.3,33.3,86.2$ and $40 \%$ of $\mathrm{Cu}, \mathrm{Co}, \mathrm{Pb}$ and $\mathrm{Mn}$, respectively, from sterilized sewage wastewater, while 75 , $11.8,100$ and $61.5 \%$ removal of $\mathrm{Cu}, \mathrm{Co}, \mathrm{Pb}$ and $\mathrm{Mn}$ was observed with mixed culture of Nostoc muscorum and Anabaena subcylindrica from sewage wastewater (ElSheekh et al. 2005). This report revealed the superiority of microalgal consortium/mixed culture in the removal of $\mathrm{Cu}$ and $\mathrm{Pb}$ from wastewater, over the use of microalgal monocultures.

Water quality improvement by microalgae in wastewater

Microalgae are presumed to have role in self-purification of natural water bodies (Sen et al. 2013). The efficiency of microalgae in water quality improvement in wastewater has been documented in various studies (Bernal et al. 2008; Riano et al. 2011). Bernal et al. (2008) demonstrated that native microalgae growing in wastewater treatment plant removed 88, 97.3, 88.6, 91.4 and $99.9 \%$ of chemical oxygen demand (COD), biological oxygen demand (BOD), total suspended solid (TSS), turbidity, fecal coliforms, respectively, from dairy sewage water in 25 days. Mata et al. (2012) studied the efficiency of Scenedesmus obliquus for the treatment of brewery effluent and revealed $20.8 \%$ removal of COD in 14 days. Chlorella sp. removed $24.8 \%$ of COD in 9 days from secondary treated municipal wastewater filtered through 0.2- $\mu \mathrm{m}$ membrane (Cho et al. 2011). Wang et al. (2010b) revealed that Chlorella sp. removed $34.3 \%$ of COD in 21 days from dairy manure effluent diluted and filtered $(1.5 \mu \mathrm{m})$. Various studies illustrated $70-90 \%$ removal of COD from municipal wastewater centrate in 9-14 days by using Chlorella sp. (Li et al. 2011b; Min et al. 2011; Wang et al. 2010a). Anabaena variabilis and A. oryzae removed 89.2 and $73.7 \%$ of $\mathrm{BOD}$ and COD, respectively, in 7 days from domestic to industrial wastewater. However, Qun et al. (2008) revealed that an algal biofilm removed $97.1 \%$ of COD in 6 days from simulated wastewater; while, a consortium of native microalgal strains removed $70 \%$ of the COD in 5 days from fish processing wastewater (Riano et al. 2011). These studies indicated that various microalgae are efficient in water quality improvement in wastewater and the use of native strains and/or consortial approach may be useful for the improving the treatment process; however, the process also depends upon the culture conditions provided and the extent of contaminants.
Future outlook

Although, the idea of using microorganisms in bioremediation dates back to 1980 , the refinement of tools and development of methods and their applications are more recent. However, several gaps still remain, which need indepth research; among which some important areas include:

- Studies on the indigenous diversity of microalgae inhabiting different wastewaters need to be complemented using molecular tools to understand the qualitative and quantitative changes in diversity with time and treatment.

- Selection and development of different types of consortia, which can acclimatize and treat wastewater generated from diverse sources. In this respect, consortia generated with native microalgae will be more beneficial, as shown in available reports.

- Consortial approach with wider biological spectrum i.e., consortia of microalgae with bacteria or fungi may further strengthen the sustenance or competitive ability of consortia, especially using native microorganisms. This can also reduce the cost of process as they can induce self-flocculation, aiding in harvesting of these consortia. However, the presence of associated pathogenic or toxic microbes should be looked into, before evaluating their ultimate use as animal feed.

- Research in the area of metagenomics is required with an emphasis to develop and evaluate the techniques/ protocols for assessment of establishment and effectiveness of inoculated versus native microalgae at the contaminated sites.

- Understanding the mechanisms of nutrient uptake and their interaction/interference by other contaminants such as heavy metals is also an important area, which is required for the success of consortial approach at commercial level.

\section{Conclusion}

The available literature in reports have clearly emphasized and proved beyond doubt that microalgae are efficient in nutrient removal from different types of wastewaters and can be explored for the remediation of these contaminated sites. The response and growth of different types of microalgae in wastewater also vary, because of differences in their inherent ability, especially nutrient uptake; tolerance to harsh/extreme environmental conditions and competitive potential, vis-a-vis indigenous organisms. Further, the difficulties encountered with the use of monocultures of microalgae, such as growth in diverse environments and 
harvesting problems, highlight that the consortial approach may be a more effective alternative for wastewater treatment. Such consortia, especially showing synergistic interactions would have wider potential in treating different types of wastewater, than microalgal monocultures. The formulation of consortia of native strains can strengthen the acceptability and wider use of phycoremediation at the industrial/commercial scale. As algae represent the base of food pyramids and primary consumer in food chains, their deployment needs to be an integral part of wastewater remediation in the global scenario, as an environmentfriendly strategy.

Acknowledgments The first author is thankful to the University Grants Commission (UGC), New Delhi for her fellowship under UGC Reference No. F.151/2007(BSR) Dated 23/03/2011. All the authors are thankful to Chairman, Department of Botany, Panjab University, Chandigarh and Division of Microbiology, Indian Agricultural Research Institute, New Delhi for providing the research facilities to carry out the present investigations.

\section{Abbreviations}

$\begin{array}{ll}\text { WHO } & \text { World Health Organization } \\ \text { CPCB } & \text { Central Pollution Control Board } \\ \text { WWTP } & \text { Wastewater Treatment plant }\end{array}$

\section{References}

Abou-Shanab RAI, Ji M, Kim H, Paeng K, Jeon B (2013) Microalgal species growing on piggery wastewater as a valuable candidate for nutrient removal and biodiesel production. J Environ Manag 115:257-264

Ajayan KV, Selvaraju M, Thirugnamoorthy K (2011) Growth and heavy metals accumulation potential of microalgae grown in sewage wastewater and petrochemical effluent. Pak J Biol Sci 14:805-811

Ali H, Khan E, Sajad MA (2013) Phytoremediation of heavy metalsconcepts and applications. Chemosphere 91:869-881

Aonghusa CN, Gray NF (2002) Laundry detergents as a source of heavy metals in Irish domestic wastewater. J Environ Sci Health A Tox Hazard Subst Environ Eng 37:1-6

Badr SA, Ghazy ME, Moghazy RM (2010) Toxicity assessment of cyanobacteria in a wastewater plant, Egypt. J Appl Sci Res 6:1511-1516

Bernal CB, Vazquez G, Quintal IB, Bussy AN (2008) Microalgal dynamics in batch reactors for municipal wastewater treatment containing dairy sewage water. Water Air Soil Pollut 190:259-270

Bhatnagar A, Bhatnagar M, Chinnasamy S, Das KC (2010) Chlorella minutissima - a promising fuel alga for cultivation in municipal wastewaters. Appl Biochem Biotech 161:523-536

Bhatnagar A, Chinnasamy S, Singh M, Das KC (2011) Renewable biomass production by mixotrophic algae in the presence of various carbon sources and wastewaters. Appl Energ 88:3425-3431

Bhola V, Swalaha F, Kumar RR, Singh M, Bux F (2014) Overview of the potential of microalgae for $\mathrm{CO}_{2}$ sequestration. Int $\mathrm{J}$ Environ Sci Technol 11:2103-2118

Cabanelas ITD, Ruiz J, Arbib Z, Chinalia FA, Garrido-Perez C, Rogalla F, Nascimento IA, Perales JA (2013) Comparing the use of different domestic wastewaters for coupling microalgal production and nutrient removal. Bioresour Technol 131:429-436

Central Pollution Control Board (2009) Status of water supply and wastewater generation and treatment in Class-I cities and ClassII towns of India-a report by CPCB (2009). http://www. indiawaterportal.org

Chinnasamy S, Bhatnagar A, Claxton R, Das KC (2010a) Biomass and bioenergy production potential of microalgae consortium in open and closed bioreactors using untreated carpet industry effluent as growth medium. Bioresour Technol 101:6751-6760

Chinnasamy S, Bhatnagar A, Hunt RW, Das KC (2010b) Microalgae cultivation in a wastewater dominated by carpet mill effluents for biofuel applications. Bioresour Technol 101:3097-3105

Cho S, Luong TT, Lee D, Oh Y, Lee T (2011) Reuse of effluent water from a municipal wastewater treatment plant in microalgae cultivation for biofuel production. Bioresour Technol 102:8639-8645

Cho S, Lee N, Park S, Yu J, Luong TT, Oh Y, Lee T (2013) Microalgae cultivation for bioenergy production using wastewaters from a municipal WWTP as nutritional sources. Bioresour Technol 13:515-520

Dubey SK, Dubey J, Viswas AJ, Tiwali P (2011) Studies on cyanobacterial biodiversity in paper mill and pharmaceutical industrial effluents. Br Biotechnol J 1:61-67

El-Sheekh MM, El-Maggar AH, Osman MEH, Haieder A (2000) Comparative studies on the green algae Chlorella homosphaera and Chlorella vulgaris with respect to oil pollution in the river Nile. Water Air Soil Pollut 124:187-204

El-Sheekh MM, El-Shouny WA, Osman MEH, El-Gammal EWE (2005) Growth and heavy metals removal efficiency of Nostoc muscorum and Anabaena subcylindrica in sewage and industrial wastewater effluents. Environ Toxicol Pharmacol 19:357-365

Fouilland E (2012) Biodiversity as a tool for waste phycoremediation and biomass production. Rev Environ Sci Biotechnol 11:1-4

Frampton DMF, Gurney RH, Dunstan GA, Clementson LA, Toifl MC, Pollard CB, Burn S, Jameson LD, Blackburn SI (2013) Evaluation of growth, nutrient utilization and production of bioproducts by a wastewater-isolated microalga. Bioresour Technol 130:261-268

Franchino M, Comino E, Bona F, Riggio VA (2013) Growth of three microalgae strains and nutrient removal from an agro-zootechnical digestate. Chemosphere 92:738-744

Furtado ALFF, Calijuri MDC, Lorenzi AS, Honda RY, Genuario DB, Fiore MF (2009) Morphological and molecular characterization of cyanobacteria from a Brazilian facultative wastewater stabilization pond and evaluation of microcystin production. Hydrobiologia 627:195-220

Ghosh S, Love NG (2011) Application of $r b c L$ based molecular diversity analysis to algae in wastewater treatment plants. Bioresour Technol 102:3619-3622

Ghosh S, Barinova S, Keshri JP (2012) Diversity and seasonal variation of phytoplankton community in the Santragachi lake, West Bengal, India. QSci Connect 3. doi:10.5339/connect.2012.3

Gonzalez C, Marciniak J, Villaverde S, Garcia-Encina PA, Munoz R (2008) Microalgae based processes for the biodegradation of pretreated piggery wastewaters. Appl Microbiol Biotechnol 80:891-898

Gupta V, Ratha SK, Sood A, Chaudhary V, Prasanna R (2013) New insights into the biodiversity and applications of cyanobacteria (blue-green algae)—prospects and challenges. Algal Res 2:79-97

Hongyang S, Yalei Z, Chunmin Z, Xuefei Z, Jinpeng L (2011) Cultivation of Chlorella pyrenoidosa in soybean processing wastewater. Bioresour Technol 102:9884-9890

Hussein NR, Gharib SM (2012) Studies on spatio-temporal dynamics of phytoplankton in El-Umum drain in west of Alexandria. Egypt J Environ Biol 33:101-105 
Ji M, Abou-Shanab RAI, Kim S, Salama E, Lee S, Kabra AN, Lee Y, Hong S, Jeon B (2013) Cultivation of microalgae species in tertiary municipal wastewater supplemented with $\mathrm{CO}_{2}$ for nutrient removal and biomass production. Ecol Eng 58:142-148

John J (2000) A self-sustainable remediation system for acidic mine voids. In: 4th International conference of diffuse pollution, pp 506-511

Kang CD, Ana JY, Park TH, Sima SJ (2006) Astaxanthin biosynthesis from simultaneous $\mathrm{N}$ and $\mathrm{P}$ uptake by the green alga Haematococcus pluvialis in primary-treated wastewater. Biochem Eng J 31:234-238

Khan FA, Ansari AA (2005) Eutrophication: an ecological vision. Bot Rev 71:449-482

Kim J, Lingaraju BP, Rheaume R, Lee J, Siddiqui KF (2010) Removal of ammonia from wastewater effluent by Chlorella vulgaris. Tsinghua Sci Technol 4:391-396

Kirkwood AE, Nalewajko C, Fulthorpe RR (2001) The occurrence of cyanobacteria in pulp and paper waste-treatment systems. Can J Microbiol 47:761-766

Lee RE (2008) Phycology, 4th edn. Cambridge University Press, New York

Levy JL, Stauber JL, Adams M, Maher W, Kirby JK, Jolly DF (2005) Toxicity, biotransformation, and mode of action of arsenic in two freshwater microalgaee (Chlorella sp. and Monoraphidium arcuatum). Environ Toxicol Chem 24:2630-2639

Li Y, Chen Y, Chen P, Min M, Zhou W, Martinez B, Zhu J, Ruan R (2011a) Characterization of a microalga Chlorella sp. well adapted to highly concentrated municipal wastewater for nutrient removal and biodiesel production. Bioresour Technol 102:5138-5144

Li Y, Zhou W, Hu B, Min M, Chen P, Ruan RR (2011b) Integration of algae cultivation as biodiesel production feedstock with municipal wastewater treatment: strains screening and significance evaluation of environmental factors. Bioresour Technol 102:10861-10867

Lim S, Chu W, Phang S (2010) Use of Chlorella vulgaris for bioremediation of textile wastewater. Bioresour Technol 101:7314-7322

Liu W, Zhang Q, Liu G (2010) Lake eutrophication associated with geographic location, lake morphology and climate in China. Hydrobiologia 644:289-299

Lizzul AM, Hellier P, Purton S, Baganz F, Ladommatos N, Campos L (2014) Combined remediation and lipid production using Chlorella sorokiniana grown on wastewater and exhaust gases. Bioresour Technol 151:12-18

Makandar MB, Bhatnagar A (2010) Morphotypic diversity of microalgae in arid zones of Rajasthan. J Algal Biomass Utln 1:74-92

Mani D, Kumar C (2014) Biotechnological advances in bioremediation of heavy metals contaminated ecosystems: an overview with special reference to phytoremediation. Int J Environ Sci Technol 11:843-872

Martins J, Peixe L, Vasconcelos V (2010) Cyanobacteria and bacteria co-occurrence in a wastewater treatment plant (WWTP): absence of allelopathic effects. Water Sci Technol 62:1954-1962

Mata TM, Melo AC, Simoes M, Caetano NS (2012) Parametric study of a brewery effluent treatment by microalgae Scenedesmus obliquus. Bioresour Technol 107:151-158

Min M, Wang L, Li Y, Mohr MJ, Hu B, Zhou W, Chen P, Ruan R (2011) Cultivating Chlorella sp. in a pilot-scale photobioreactor using centrate wastewater for microalgae biomass production and wastewater nutrient removal. Appl Biochem Biotechnol 165:123-137

Mustafa E, Phang S, Chu W (2012) Use of an algal consortium of five algae in the treatment of landfill leachate using the high-rate algal pond system. J Appl Phycol 24:953-963
Mutanda T, Karthikeyan S, Bux F (2011) The utilization of postchlorinated municipal domestic wastewater for biomass and lipid production by Chlorella spp. under batch conditions. Appl Biochem Biotechnol 164:1126-1138

Nacorda JO, Martinez-Goss MR, Torreta NK, Merca FE (2007) Metal resistance and removal by two strains of the green alga, Chlorella vulgaris Beijerinck, Isolated from Laguna de Bay, Philippines. J Appl Phycol 19:701-710

Nyholm N, Ingerslev F, Berg UT, Pederson JP, Frimer-Larsen H (1996) Estimation of kinetic rate constants for biodegradation of chemicals in activated sludge wastewater treatment plants using short term batch experiments and microgram/L range spiked concentration. Chemosphere 33:851-864

Oswald WJ (1988) The role of micro algae in liquid waste treatment and reclamation. In: Lembi CA, Waaland JR (eds) Algae and human affairs. Cambridge University Press, Cambridge, pp 225-281

Oswald WJ, Gotaas HB (1955) Photosynthesis in sewage treatment. Proceedings separate-686, Proc Am Soc Civil Eng, pp 73-105

Oswald WJ, Gotaas HB, Golueke CG, Kellen WR (1957) Algae in wastewater treatment. Sew Ind Wastes 29:437-455

Petrovic M, Gonzalez S, Barcelo D (2003) Analysis and removal of emerging contaminants in wastewater and drinking water. Trends Anal Chem 22:685-696

Pittman JK, Dean AP, Osundeko O (2011) The potential of sustainable algal biofuel production using wastewater resources. Bioresour Technol 102:17-25

Qun W, Zhiquan H, Genbao L, Bo X, Hao S, Meiping T (2008) Removing nitrogen and phosphorus from simulated wastewater using algal biofilm technique. Front Environ Sci Eng 2:446-451

Radjenovic J, Petrovic M, Barcelo D (2009) Fate and distribution of pharmaceuticals in wastewater and sewage sludge of the conventional activated sludge (CAS) and advanced membrane bioreactor (MBR) treatment. Water Res 43:831-841

Rawat I, Kumar RR, Mutanda T, Bux F (2011) Dual role of microalgae: phycoremediation of domestic wastewater and biomass production for sustainable biofuels production. Appl Energ 88:3411-3424

Razzak SA, Hossain MM, Lucky RA, Bassi AS, de Lasa H (2013) Integrated $\mathrm{CO}_{2}$ capture, wastewater treatment and biofuel production by microalgae culturing - a review. Renew Sust Energ Rev 27:622-653

Renuka N, Sood A, Ratha SK, Prasanna R, Ahluwalia AS (2013a) Nutrient sequestration, biomass production by microalgae and phytoremediation of sewage water. Int J Phytoremed 15:789-800

Renuka N, Sood A, Ratha SK, Prasanna R, Ahluwalia AS (2013b) Evaluation of microalgal consortia for treatment of primary treated sewage effluent and biomass production. J Appl Phycol 25:1529-1537

Renuka N, Sood A, Prasanna R, Ahluwalia AS (2014) Influence of seasonal variation in water quality on the microalgal diversity of sewage wastewater. S Afr J Bot 90:137-145

Riano B, Molinuevo B, Garcia-Gonzalez MC (2011) Treatment of fish processing wastewater with microalgae-containing microbiota. Bioresour Technol 102:10829-10833

Richards RG, Mullins BJ (2013) Using microalgae for combined lipid production and heavy metal removal from leachate. Ecol Model 249:59-67

Ruiz-Marin A, Mendoza-Espinosa LG, Stephenson T (2010) Growth and nutrient removal in free and immobilized green algae in batch and semi-continuous cultures treating real wastewater. Bioresour Technol 101:58-64

Ruiz-Martinez A, Garcia NM, Romero I, Seco A, Ferrer J (2012) Microalgae cultivation in wastewater: nutrient removal from anaerobic membrane bioreactor effluent. Bioresour Technol $126: 247-253$ 
Ryu B, Kim K, Kim J, Han J, Yang J (2013) Use of organic waste from the brewery industry for high-density cultivation of the docosahexaenoic acid-rich microalga, Aurantiochytrium sp. KRS101. Bioresour Technol 129:351-359

Sahu AK, Siljudalen J, Trydal T, Rusten B (2013) Utilization of wastewater nutrients for microalgae growth for anaerobic digestion. J Environ Manag 122:113-120

Samori G, Samor C, Guerrini F, Pistocchi R (2013) Growth and nitrogen removal capacity of Desmodesmus communis and of a natural microalgae consortium in a batch culture system in view of urban wastewater treatment: part I. Water Res 47:791-801

Sen B, Alp MT, Sonmez F, Kocer MAT, Canpolat O (2013) Relationship of algae to water pollution and waste water treatment. In: Elshorbagy W (ed) Water treatment, ISBN: 978-953-51-0928-0, InTech. http://www.intechopen.com/books/ water-treatment/relationship-of-algae-to-water-pollution-andwaste-water-treatment

Shanthala M, Hosmani SP, Hosetti BB (2009) Diversity of phytoplanktons in a waste stabilization pond at Shimoga town, Karnataka State, India. Environ Monit Assess 151:437-443

Silva-Benavides AM, Torzillo G (2011) Nitrogen and phosphorus removal through laboratory batch cultures of microalgae Chlorella vulgaris and cyanobacterium Planktothrix isothrix grown as monoalgal and as co-cultures. J Appl Phycol 24:267-276

Singh UB, Ahluwalia AS (2013) Microalgae: a promising tool for carbon sequestration. Mitig Adapt Strateg Glob Chang 18:73-95

Singh G, Thomas PB (2012) Nutrient removal from membrane bioreactor permeate using microalgae and in a microalgae membrane photoreactor. Bioresour Technol 117:80-85

Singh M, Reynolds DL, Das KC (2011) Microalgal system for treatment of effluent from poultry litter anaerobic digestion. Bioresour Technol 102:10841-10848

Sood A, Uniyal PL, Prasanna R, Ahluwalia AS (2012) Phytoremediation potential of aquatic macrophyte, Azolla. Ambio 41:122-137

Souza PO, Ferreira LR, Pires NRX, Filho PJS, Duarte FA, Pereira CMP, Mesko MF (2012) Algae of economic importance that accumulate cadmium and lead: a review. Braz J Pharmacogn $22: 825-837$

Spolaore P, Joannis-Cassan C, Duran E, Isambert A (2006) Commercial applications of microalgae. J Biosci Bioeng 101:87-97

Starckx S (2012) A place in the sun-algae is the crop of the future, according to researchers in Geel, Flanders Today. http://www. flanderstoday.eu/content/place-sun

Su Y, Mennerich A, Urbana B (2012a) Synergistic cooperation between wastewater-born algae and activated sludge for wastewater treatment: influence of algae and sludge inoculation ratios. Bioresour Technol 105:67-73
Su Y, Mennerich A, Urbana B (2012b) Comparison of nutrient removal capacity and biomass settleability of four high-potential microalgal species. Bioresour Technol 124:157-162

Sydney EB, da Silva TE, Tokarski A, Novak AC, de Carvalho JC, Woiciecohwski AL (2011) Screening of microalgae with potential for biodiesel production and nutrient removal from treated domestic sewage. Appl Energ 88:3291-3294

Thiel T (1988) Phosphate transport and arsenate resistance in the cyanobacterium Anabaena variabilis. J Bacteriol 170:1143-1147

Vasconcelos VM, Pereira E (2001) Cyanobacteria diversity and toxicity in a wastewater treatment plant (Portugal). Water Res 35:1354-1357

Vijayakumar S, Thajuddin N, Manoharan C (2007) Biodiversity of cyanobacteria in industrial effluents. Acta Bot Malacit 32:27-34

Wang B, Lan CQ (2011) Biomass production and nitrogen and phosphorus removal by the green alga Neochloris oleoabundans in simulated wastewater and secondary municipal wastewater effluent. Bioresour Technol 102:5639-5644

Wang L, Li Y, Chen P, Min M, Chen Y, Zhu J, Ruan RR (2010a) Anaerobic digested dairy manure as a nutrient supplement for cultivation of oil-rich green microalgae Chlorella sp. Bioresour Technol 101:2623-2628

Wang L, Min M, Li Y, Chen P, Chen Y, Liu Y, Wang Y, Ruan RR (2010b) Cultivation of green algae Chlorella sp. in different wastewaters from municipal wastewater treatment plant. Appl Biochem Biotechnol 162:1174-1186

Wang H, Xiong H, Hui Z, Zeng X (2012) Mixotrophic cultivation of Chlorella pyrenoidosa with diluted primary piggery wastewater to produce lipids. Bioresour Technol 104:215-220

Wang H, Hu Z, Xiao B, Cheng Q, Li F (2013) Ammonium nitrogen removal in batch cultures treating digested piggery wastewater with microalgae Oedogonium sp. Water Sci Technol 68:269-275

WHO and UNICEF Joint Monitoring Programme (2000) Global water supply and sanitation assessment report. New York: UNICEF and Geneva: WHO

Wu LF, Chen PC, Huang AP, Lee CM (2012) The feasibility of biodiesel production by microalgae using industrial wastewater. Bioresour Technol 113:14-18

Yang X, Wu X, Hao H, He Z (2008) Mechanisms and assessment of water eutrophication. J Zhejiang Univ Sci B 9:197-209

Zhou W, Li Y, Min M, Hu B, Zhang H, Ma X, Li L, Cheng Y, Ruan R (2012) Growing wastewater-borne microalga Auxenochlorella protothecoides UMN280 on concentrated municipal wastewater for simultaneous nutrient removal and energy feedstock production. Appl Energ 98:433-440

Zhu L, Wang Z, Takala J, Hiltunen E, Qin L, Xu Z, Qin X, Yuan Z (2013) Scale-up potential of cultivating Chlorella zofingiensis in piggery wastewater for biodiesel production. Bioresour Technol 137:318-325 